\title{
Enhancing Supplier's Involvement in Startup's Innovation through Equity Offering and Trust Building
}

Song, Michael; de Jong, Ad; Di Benedetto, C. Anthony; Zhao, Y. Lisa

\author{
Document Version \\ Accepted author manuscript \\ Published in: \\ International Journal of Innovation Management
}

DOI:

$10.1142 / \mathrm{S} 1363919619500130$

Publication date:

2019

License

Unspecified

Citation for published version (APA):

Song, M., de Jong, A., Di Benedetto, C. A., \& Zhao, Y. L. (2019). Enhancing Supplier's Involvement in Startup's Innovation through Equity Offering and Trust Building. International Journal of Innovation Management, 23(2),

[1950013]. https://doi.org/10.1142/S1363919619500130

Link to publication in CBS Research Portal

\section{General rights}

Copyright and moral rights for the publications made accessible in the public portal are retained by the authors and/or other copyright owners and it is a condition of accessing publications that users recognise and abide by the legal requirements associated with these rights.

\section{Take down policy}

If you believe that this document breaches copyright please contact us (research.lib@cbs.dk) providing details, and we will remove access to the work immediately and investigate your claim.

Download date: 26. Apr. 2023
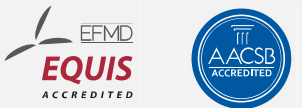


\section{Enhancing Supplier's Involvement in Startup's Innovation through Equity Offering and Trust Building}

\section{Michael Song, Ad de Jong, C. Anthony Di Benedetto, and Y. Lisa Zhao}

Journal article (Accepted manuscript*)

\section{Please cite this article as:}

Song, M., de Jong, A., Di Benedetto, C. A., \& Zhao, Y. L. (2019). Enhancing Supplier's Involvement in Startup's Innovation through Equity Offering and Trust Building. International Journal of Innovation Management, 23(2), [1950013]. https://doi.org/10.1142/\$1363919619500130

DOl: https://doi.org/10.1142/\$1363919619500130

Uploaded to CBS Research Portal in accordance with World Scientific Publishing's Open Access policy: https://www.worldscientific.com/page/authors/author-rights\#Preprint

* This version of the article has been accepted for publication and undergone full peer review but has not been through the copyediting, typesetting, pagination and proofreading process, which may lead to differences between this version and the publisher's final version AKA Version of Record. 
SUPPLIER INVOLVEMENT IN STARTUP INNOVATION

\title{
ENHANCING SUPPLIER'S INVOLVEMENT IN STARTUP'S INNOVATION THROUGH EQUITY OFFERING AND TRUST BUILDING
}

\begin{abstract}
External partners, such as suppliers, are important in the case of innovation by entrepreneurial startup firms. Due to their limited resources and liability of newness, these startups must rely on outside partners for resources and legitimacy to succeed and indeed to survive. Yet few studies have specifically examined, or provided guidance on, how startups can increase supplier involvement in their innovation projects. Drawing from Transactional Cost Economics and supplier involvement literature, this study develops a contingency model, in which supplier's equity share and supplier's trust moderate the relationship of supplier's involvement in a startup's innovation with supplier's specific investment and startup's effort in qualification of supplier's ability. We empirically test the model using data collected from 166 innovation projects of 166 startups. Our results show that supplier involvement is pivotal to startup's product innovation performance, which is consistent with prior literature on supplier involvement. Interestingly, our results further reveal that supplier's specific investment and startup's effort in qualification of supplier's ability lead to higher levels of supplier involvement only when supplier's equity share and supplier's trust are sufficiently high.
\end{abstract}


SUPPLIER INVOLVEMENT IN STARTUP INNOVATION

\section{INTRODUCTION}

It has been noted that supplier involvement in startup innovation is related to increased innovation performance (Jean et. al., 2014; Song \& Di Benedetto, 2008). External partners, such as suppliers, are important in the case of innovation by entrepreneurial startup firms. Due to their limited resources and liability of newness, these startups must rely on outside partners for resources and legitimacy to succeed and indeed to survive (Buskirk \& Lavik, 2004; Gilbert, McDougall, \& Audretsch, 2006; Lodish, Morgan, \& Kallianpur, 2001; Marion, Friar, \& Simpson, 2012; Shepherd, Duglas, \& Shanley, 2000). Yet, the literature has paid extensive research attention to governance mechanisms of supplier relationship for established firms (e.g., Harland, 1996; Cousins \& Lawson, 2007; Jean et. al., 2014), though relatively little attention to governance mechanisms that specifically apply to supplier involvement with startups.

Startups face a particular set of challenges when seeking a supplier partner for innovation. First, many startups lack the trust of the prospective suppliers due to their lack of reputation, resources, or experience (Read, Dew, Sarasvathy, Song, \& Wiltbank, 2009). This increases the supplier's contractual hazard of doing business with the startup (Geyskens, Steenkemp \& Kumar, 2006). Second, a startup may receive very limited attention from capable suppliers since the organization, and often its innovative product, are in early development stage and likely to change over time (Lee, 2002). Therefore, startups must invest resources in qualifying potential suppliers in terms of the skills and abilities that they possess; get them interested in and encourage them to be involved in the startup's innovation.

Past research by Song and Di Benedetto (2008) has identified supplier's specific investment in the startup and startup's effort in qualifying supplier's ability as important drivers for supplier's involvement in the startup's innovation. Other studies, however, suggest that 
boundary conditions play important roles in inter-firm transactions (David \& Han, 2004;

Geyskens et al., 2006; Martinez \& Dacin, 1999; Schepker, Oh, Martynov, \& Poppo, 2013). In this setting, traditional formal governance mechanisms, like supplier's specific investments in the new startup and the startup's investment in qualifying supplier's capability, as identified by Song and Di Benedetto (2008), may not fully explain supplier involvement. The effectiveness of these two mechanisms may be contingent on some important boundary conditions. These governance mechanisms may be less effective and its effects often just are of short-term, while the evolving innovation requires the supplier make continuing specific investment and develop its capabilities over a longer period of time. Even after a qualified supplier makes an initial specific investment in the startup, the startup needs to search for other suitable mechanisms that can mitigate the reduced effectiveness of the traditional mechanisms (Le Breton-Miller \& Miller, 2006). In sum, the literature on this topic has focused on antecedents to supplier involvement (such as supplier's specific investments and startup's qualification of supplier's capability (Song \& Di Benedetto 2008)), without regard for factors that may change through time and either maintain the supplier's desire to continue working with the startup, or cause an initially favorable supplier-startup relationship to erode, and diminish the supplier's intention to stay involved in the long term.

This study seeks to fill the literature gap by examining two long-term mechanisms that specifically are relevant to governing continued supplier involvement in the startup's NPD process: trust and equity (Lumpkin \& Brigham, 2011). First, by behaving appropriately toward its supplier, the startup can build on trust created at the beginning of the relationship, thus reducing supplier's risk and supporting even greater supplier involvement through time. Therefore, trust, as an informal governance mechanism, is essential in overcoming the challenge 
of obtaining supplier involvement (Brattström \& Richtnér, 2013; Ebers \& Oerlemans, 2016; Read et al., 2009; Zhong, Su, Peng, \& Yang, 2017). Second, by giving a part of ownership of the firm to the supplier through equity shares, the startup gives the supplier the opportunity to share the success of the startup's innovation in the long run, compensating for the initial risks that the supplier has to take. Taking an equity stake in the startup also gives the supplier some degree of control over the startup's innovation process, motivating the supplier to further increase its involvement as its own profitability is tied to the startup's success. That is, building trust and offering an equity share are actionable mechanisms that can be used by the startup to maintain, or even further grow, the supplier's initial levels of trust into the long term, and offset any possible decline in the effectiveness of the mechanisms that characterized the relationship in its initial stages (Le Breton-Miller \& Miller, 2006).

This study makes several contributions. First, the results of our study expand the TCE literature on boundaries by uncovering supplier's trust and startup's equity share as effective governance mechanisms that play a moderating role in leveraging other formal mechanisms as drivers of supplier involvement in startup product innovation. Second, we examine formal and informal mechanisms that are under the control of the startup and are particularly relevant to the long-tern orientation of startup processes and outcomes. Thus, we offer important management implications for entrepreneurs to overcome resource limitations and liability of newness and to succeed in their innovation projects.

\section{CONCEPTUAL FRAMEWORK}

Supplier involvement has been described in the literature in terms of integration of capabilities, resources, or information sharing. Van Echtelt, Wynstra, Van Weele \& Duysters (2008) defined supplier involvement as "the resources that suppliers provide, the tasks they carry 
out and the responsibilities they assume for the benefit of a buyer's current or future product development projects." This study defines a supplier as one of the top three suppliers who provide components and/or materials for a startup to use in an innovation project. In the literature, a dominant theoretical perspective for studying inter-firm relationships is Transaction Cost Economics (TCE) (e.g., Grover \& Malhotra 2003; Cousins 2005; Jean et.al., 2014).

A fundamental principle of TCE is that there are hazards in any kind of transaction and these hazards present risks to the participants and reduce the value of the transaction (Williamson, 1985). To overcome these risks and to allow the transaction to take place, the participants enter into a governance structure that reduces transaction costs and/or minimizes opportunistic behavior (Williamson, 1983, 1985). This control-based approach focuses on minimizing costs for the individual firm in inter-organizational exchanges and reducing risks that are inherent to investments in the partner firm by means of effective governance mechanisms.

Governance can take the form of formal governance, such as hierarchical governance within the firm, contractual safeguards or guarantees between two or more firms, or more informal relational mechanisms, such as mutual dependence or trust (Heide, 1994; Bradach \& Eccles, 1989; Geyskens et al., 2006; Leiblein, 2003; Liu, Luo \& Liu, 2009; Schepker et al., 2014; Zhong et al., 2017). Further, while TCE usually depicts formal governance mechanisms as the results of planned, intentional actions of the participants, relational governance mechanisms such as trust can accumulate over time spontaneously (Noorderhaven, 1994). Startups can motivate suppliers to be involved in their innovation through both formal and relational governance.

From the supplier's perspective, startups are not desirable partners in terms of transaction cost economics. Startups lack a track record with suppliers and have limited financial and human resources (Marion et al., 2012). Thus, the supplier lacks information regarding the startup and 
has to incur learning costs (Wathne, Biong, \& Heide, 2001). In addition, a startup's innovation is often uncertain and evolving, which may require the supplier to continuously make specific investment and modify its configuration to meet the startup's needs. Therefore, a supplier faces considerable uncertainties in entering a relationship with a startup, which increase transaction costs.

From the startup's perspective, it needs supplier's resources and skills to succeed in its innovation. Nevertheless, since its organization and innovation are still evolving (or uncertain), it has a very limited range of suppliers that can meet its needs (Lee, 2002). It has to spend resources to search for qualified suppliers and implement effective governance mechanisms to motivate them to be involved. A choice of the wrong supplier can result in relationship breakdown, which may lead to bankruptcy or disbandment of the startup.

Once the relationship starts (e.g., a qualified supplier has shown some commitment to the startup's innovation), the startup can act in ways to boost supplier trust (the role of trust is discussed at length later). The startup can also give the supplier an opportunity to control and share the success of the innovation through offering the supplier equity shares.

In our framework (see Figure 1), the startup's effort in qualifying suppliers (qualification of supplier's abilities) is a specific investment by the startup, while the supplier's specific investment is the investment by the supplier in the partnership, both of which are intentional mechanisms implemented by the relationship partners to reduce transaction risk and build initial trust. These represent the commitment and qualification of capabilities of the partners. The results from Song and Di Benedetto (2008) suggest that supplier's specific investment and qualification of supplier's abilities are positively related to the level of supplier's involvement in the startup' innovation. Nevertheless, we argue that the initial commitment and qualification of 
capability may not be sufficient in an entrepreneurial setting, and their effects can be of shortterm, while the evolving startup's innovation requires the supplier make a longer-term commitment and develop its capabilities over a longer period time to meet the startup's evolving needs. Startups can design and develop formal and informal governance to maintain and grow the initial commitment and qualification of the relationship partners. Equity share and trust have been identified as formal and informal governance mechanisms. We propose that the startup can motivate the supplier to increase its commitment to the startup's innovation by building trust through time (once the relationship is initiated as each party becomes more familiar with the other) and offering the supplier equity shares. Trust is an informal relational mechanism while equity share is a formal governance mechanism. This study examines how these informal and formal mechanisms serve as boundary conditions in reducing transaction costs and benefiting both parties.

Insert Figure 1 about here

\section{Determinants of Supplier Involvement}

TCE suggests that the supplier's specific investment increases supplier's desire to be involved in the startup's innovation (e.g., Williamson, 1985; Jean et al., 2014). The startup's effort to qualify the suppliers can be considered as the startup's specific investment in selecting the suppliers, and it should increase the supplier involvement as well. Previous research has provided evidence that supplier's specific investments and qualification of supplier's abilities are two important key determinants driving supplier involvement (Song \& Di Benedetto, 2008). 
Startup innovation often requires that suppliers make a specific investment. For example, the supplier's production system may need to be adjusted to the specific requirements of the startup: investments in specialized tools and equipment, adaptations to technological standards to the needs of the startup firm, or investments in worker training that cannot easily be adapted for use with other customer firms (Stump \& Heide, 1996). Specific investments therefore pose risks to the supplier, which are magnified if the firm is a startup whose long-term success is not guaranteed. The supplier may never recoup the losses associated with the specific investment. To overcome these risks and safeguard its investment, the supplier may choose to increase its involvement in the startup (Song \& Di Benedetto, 2008).

The startup's effort to qualify the supplier's abilities is the specific investment made by the startup and acts as a formal governance mechanism that affects the level of supplier involvement (Heide \& John, 1990; Song \& Di Benedetto, 2008; Spekman, 1988; Stump \& Heide, 1996; Van Echtelt et al., 2008). As discussed above, startups often have a very limited number of qualified suppliers. To prevent the problems of selecting the wrong supplier, the startup must spend resources to subject the supplier to a qualification program (Zenz, 1994). By using a solid supplier qualification process, the startup can economize on investments in monitoring the relationship (Casson, 1991). The startups make a great effort to evaluate the supplier's capabilities are likely to take measures to increase the involvement of the supplier so it can leverage the supplier's resources in its innovation. The great effort in evaluating supplier's ability reduces the uncertainty of the transaction and sends a positive signal to the supplier. If a supplier allows itself to undergo the qualification process, it shows a willingness to share information about its resources and competencies to the startup, and to get involved with the startup (Stump \& Heide, 1996). Therefore, an increase in the startup's effort to evaluate the supplier's 
qualification is related to a reduction of risk on the part of the supplier and an increase in supplier involvement in the startup (Song \& Di Benedetto, 2008).

\section{Boundary Conditions}

Supplier's specific investment and startup's qualification of supplier's abilities may not always be effective as drivers of supplier involvement, but their effectiveness may be contingent on some important boundary conditions. Supplier's equity position and trust in the startup can be considered important boundary conditions that specifically apply to supplier involvement with startups.

First, the startup can reduce uncertainty about its long-term benefits, for example, through an intentional formal governance mechanism such as offering the supplier an equity stake. This reduces the supplier's uncertainty, since it is compensated for taking on the risk of entering into the partnership by a share of the profits if the startup is successful. In addition, an important source of transaction cost is uncertainty about the startup's objectives and, in particular, whether the startup is acting in its own self-interests. The equity share also gives the supplier a degree of control over the startup.

Secondly, startups also need to consider the impact of relational mechanisms. Several TCE scholars have shown that relational mechanisms may act as moderating variables (for example, Artz \& Brush, 2000). Trust has been shown to lower transaction costs of exchange (Buvik \& John, 2000), and to lead to greater integration between transacting parties over and above transaction cost factors (Gulati, 1995; Oxley, 1997; Zaheer \& Venkatraman, 1995). It takes time to build trust; however, given the startup's predominant focus on long-term benefits, trust between the supplier and startup is required to overcome this cost and achieve long-term cooperation. Startup must find a way to capitalize on any trust it has earned in the supplier 
qualification process, and to build this trust in a relatively short time frame. This is consistent with the literature that emphasizes the developmental and dynamic nature of inter-firm cooperation and the importance of relational mechanisms, like trust, to successfully build such long-term interfirm relationships (Corsten \& Kumar, 2005; Dyer, 1997; Dyer and Singh, 1998; Geyskens et al., 2006; Liu et al., 2009; Mesquita, Anand, \& Brush, 2008; Van Echtelt et al., 2008; Zajac \& Olsen, 1993).

Contingency Role of Supplier's Equity Share. We define supplier's equity share as the percentage of the startup's equity owned by the supplier. Several studies have examined the role of equity investments in startups in high-tech industries (e.g., Dushnitsky \& Lenox, 2005). Studies on network partner involvement have indicated the importance of private equity investments to financially support the NPD process of high-tech startups (Chesbrough, 2003). So far, however, how the offering of financial rewards, like equity shares, by the startup itself to its investing supplier affects transaction costs has received little research attention.

We expect that supplier's equity share in the startup facilitates (moderates) the effect of supplier's specific investments on supplier involvement. As startups often have few resources and little or no reputation, equity shares may be offered to mitigate opportunism. Offering an equity share implies that the supplier shares the startup's uncertainties. That is, the supplier's return on its specific investment is not only contractual (i.e., fixed at a certain level), but is also tied with the startup's performance. If the startup performs poorly, there are adverse consequences to the supplier, who may even receive lower returns on the specific investment than it would have under a purely contractual arrangement. Conversely, if the startup does well, the supplier shares the profit in a proportion determined by the size of the equity share (Jensen \& Thursby, 2001). Thus, the supplier involvement is likely to be higher in an equity share 
arrangement than with only contractual, fixed returns. The supplier with a high equity share is more motivated to adjust its production system to the startup's specific requirements.

Offering the supplier an equity share also creates a situation where the partners are mutual hostages (Williamson, 1983). Thus, when controlling opportunistic behavior is the priority, equity alliances in terms of shared equity ownership may be an effective governance mechanism (Geringer \& Hebert, 1989; Sohn, 1994). Other studies emphasized the controlling function of equity share (Blodgett, 1991; 1992; Lecraw, 1984). Some scholars argued that equity ownership may also act as a distribution mechanism (Das \& Teng, 1998; Mjoen \& Tallman, 1997), where the firms that contribute most tangible and intangible resources should get the most equity shares. We posit:

Hypothesis 1a: An increase in supplier's equity share will increase the positive relationship between supplier's specific investments and the level of supplier's involvement in the startup's innovation process.

In addition, we expect supplier's equity share to positively moderate the effect of startup's effort in qualification of supplier's abilities on supplier involvement. If a supplier is selected after the startup makes a great effort to evaluate its abilities, the supplier is likely a good partner for the startup. If the startup offers a larger stake of its equity to the supplier, it will become financially more attractive to a properly qualified supplier to contribute abilities and resources to the startup's innovation process. For such well-qualified supplier, the economic advantages to create and exploit opportunities by integrating its skills and resources with the startup's resources and creating mutual understanding of each other's technologies are clearly higher. Accordingly, a properly qualified supplier is likely to exert more effort in the startup's product development efforts. The greater the supplier's equity share, the greater is the supplier's 
motivation to increase its involvement in the startup's product development process. In addition, the supplier's motivation to become involved is greater when the supplier exerts a high degree of control over the startup, as the supplier will be more informed about the startup's operations and will be better able to adjust its production system to fit the startup's requirements. We posit:

Hypothesis 1b: An increase in a supplier's equity share will increase the positive relationship between qualification of supplier's abilities and the level of supplier's involvement in the startup's innovation process.

The Contingency Role of Supplier's Trust in the Startup. Our conceptualization of trust draws on that of Morgan and Hunt (1994, p 23) who define trust as "existing when one party has confidence in an exchange partner's reliability and integrity," and Moorman, Zaltman and Deshpande (1992, p. 315), for whom "trust is defined as a willingness to rely on an exchange partner in whom one has confidence..." Trust here refers to the confidence one party has in the integrity and reliability of the trusted other party's actions and intentions. In the case of supplierstartup relationships, trust stands for the supplier's positive expectations about the startup's motives with respect to itself throughout the alliance. Morgan and Hunt (1994) argue that trust stimulates managers to maintain relationships with exchange partners, to ignore attractive shortterm alternatives in favor of the expected long-term benefits of staying with existing partners, and to consider high-risk action as being prudent, because they believe that their partners will not act opportunistically. Trust has been identified as an important inhibitor of the risk and uncertainty that undermine collaborative relationships in entrepreneurial settings (Welter, 2012). Trust is also considered as a factor that inhibits opportunistic behavior in cooperative relationships (Uzzi, 1996), limiting monitoring costs and smoothing information transfer (Larson, 1992; Payne, Davis, Moore, \& Bell, 2009; Shane \& Cable, 2002; Sapienza \& Korsgaard, 1996; Squire, 
SUPPLIER INVOLVEMENT IN STARTUP INNOVATION

Cousins, \& Brown, 2009). Successful long-term partnerships are typically the result of informal, interpersonal interaction between firms, in which trust is a critical social process (Zajac \& Olsen, 1993).

Recent research shows that trust in entrepreneurial settings is a long-term process over time and that trust is built in different ways in the early versus the later phases (Scarbrough, Swan, Amaeshi, \& Briggs, 2013). Supplier partner's initial trust in the startup may be institutional in nature and be based on supplier's knowledge about the prior experience and competences of the startup's management team and key personnel. Later on, trust may be more based on the process of repeated interactions between the supplier partner and the startup (Korsgaard, Brower, and Lester, 2015).

The TCE literature usually depicts trust as an informal, relational governance mechanism and increasingly suggest that firms should not only consider formal but also informal mechanisms to limit uncertainty and restrain partner opportunism (Geyskens et al., 2006; Liu et al., 2009). TCE is, however, inconclusive about as to whether formal and relational governance mechanism substitute or complement each other. On the one hand, the majority of studies suggest that relational governance mechanisms, like trust, relational norms, and company reputation act as substitutes for formal governance (e.g., Corts \& Singh, 2004; Gulati, 1995; Gulati \& Nickerson, 2008; Lumineau, 2017). On the other hand, several studies have found that relational governance may complement formal mechanisms (Argyres, Bercovitz, \& Mayer, 2007; Luo, 2002; Mayer \& Argyres, 2004).

We hypothesize that supplier's trust will substitute and thus weaken the impact of supplier's specific investments on supplier involvement. Trust implies confidence in and positive expectations about the startup's performance and may therefore reduce the extensiveness of 
formal governance (Das \& Teng, 1998) and decrease concerns about opportunism (Nooteboom, Berger, \& Noorderhaven, 1997). Hence, if its trust in the startup is high, the supplier is less concerned about safeguarding their investment in the new venture and can economize on costly formal governance mechanisms. If, however, its trust in the startup is low, the supplier may have to rely more on these mechanisms. Hence, suppliers making higher levels of specific investments in startups are more likely to be involved the startups under lower levels of supplier's trust. We posit:

Hypothesis 2a: An increase in supplier's trust in the startup will decrease the positive relationship between supplier's specific investments and the level of supplier's involvement in the startup's innovation process.

On the other hand, supplier's trust in the startup strengthens the effect of startup's effort in supplier qualification on supplier involvement. Trust can facilitate economic exchanges (Liu et al., 2009) through enhanced attachment and joint responses. For the supplier that the startup selects after a great effort expended during the qualification process, transaction costs can be reduced if the startup succeeds, grows, and stays loyal to the supplier. Suppliers that have a high level of trust in the startup may help the startup to exploit the relationship-specific opportunities and consolidate the situation of reduced transaction costs (Seabright, Levinthal, \& Fichman, 1992). A highly qualified supplier knows that it can help the startup to succeed. If the supplier also trusts the startup's actions and intentions, its effort is more likely to pay off. As a result, properly qualified suppliers can reap more benefits from the cooperation with the startup. We propose the hypothesis: 
Hypothesis 2b: An increase in a supplier's trust in the startup will increase the positive relationship between qualification of supplier's abilities and the level of supplier's involvement in the startup's innovation process.

\section{METHODS}

\section{Data}

The initial sample frame included 982 privately held fast growing startups listed in 19952000 Inc 500. We selected a key informant from each of the companies based on the information reported in Dun \& Bradstreet Market Identifiers database. The key informant was one of the original founders and held at least $10 \%$ of the equity stake of the company. A survey was designed based on the literature and our initial field research on three of the companies. Mail surveys were administered following the procedures described by Dillman (1978). The informant was requested to focus on one recent innovation project of the startup and provide the required data on the project. The data used in this study is from166 innovation projects of 166 startups. Of the final sample, average age of key informants was 43 years. On average, firms in the final sample had 37 to 423 employees (with an average of 253).

Nonresponse-Bias. We tested the potential nonresponse bias using the Armstrong and Overton (1977) extrapolation method. We performed a MANOVA on performance and involvement variables between the early response group (i.e., those respondents that filled out and returned the questionnaires during the first mailing) and later response group (those that had received two reminders and a second questionnaire mailing, and filled out and returned the questionnaires on the second mailing). We did not find any significance differences (at 95\% confidence level) between the two groups. 


\section{Study Measures and Measurement Model Validation}

Study Measures. All scales and measures have been previously well-established, properly defined, and validated in the literature. Table 1 presents a detailed overview of the measures used in this study.

Supplier's Specific Investment describes the investments made by a supplier specifically to fit the requirements of the startup. We used five items, which were based on Stump and Heide (1996). Qualification of Supplier's Abilities describes the level of effort expended by the startup in evaluating the supplier's skills in areas such as technical capability, compatibility of production, product quality, financial strength, and delivery capability. The five items were adapted from Stump and Heide (1996). Supplier's Trust in the startup describes the extent to which the supplier believes the startup has high integrity, communicates accurately what customers want with a high degree of accuracy, and can be counted on to do what is right. This three-item scale is based on items used by Anderson and Narus (1990) and Morgan and Hunt (1994) as well as field research. Level of Supplier Involvement refers to the extent of information sharing, coordination, and joint involvement in product design, product testing, and product commercialization. The construct was measured on a three-item scale adapted from Stump and Heide (1996). Supplier's Equity Share was measured as a percentage of the startup's total shares.

In addition to the focal variables (supplier specific investment and qualification of supplier) and contingency variables (supplier equity share and supplier trust in the startup), we also included two sets of control variables: industry dummies and other characteristics (buyer power, supplier power, threat of entry, threat of substitution, and intensity of competitive rivalry) that may not be captured by the industry dummies. The control variables were chosen as they are widely used in similar studies to control for possible estimate bias from industry effects. 
SUPPLIER INVOLVEMENT IN STARTUP INNOVATION

The items that measure supplier specific investment, qualification of supplier, supplier trust, and supplier involvement were measured on a 0-10 Likert scale. Each of the characteristic control variables was measured by a single 1-7 Likert scale item, and the data were the survey in Song \& Di Benedetto (2008).

Insert Table 1 about here

Measurement Model Validation and Descriptive Statistics. For the multi-item scales (Supplier's Specific Investment, Qualification of Supplier's Abilities, Supplier's Trust, and level of Supplier Involvement) we first performed an exploratory factor analysis (EFA), which generated four dimensions with each item loaded to the right construct as shown in Table 2 . We then conducted a confirmatory factor analysis (CFA) to further validate the measurement model. We establish the unidimensionality and convergent validity by factor loadings, the overall fit of the measurement model, the standardized residuals, and Cronbach Alpha reliabilities (Gerbing \& Anderson, 1992). The results presented in Table 2 show that all items have significant loadings on their expected constructs (at $\mathrm{p}<0.01$ ). The overall fit indices for our measurement model are: $\chi^{2} / \mathrm{d} . \mathrm{f}=2.39 ; \mathrm{GFI}=0.87 ; \mathrm{CFI}=0.93 ; \mathrm{RMSEA}=0.09$. The smallest Alpha is 0.73 .

Insert Table 2 about here

We examine discriminant validity by pair-wise chi-square difference tests and comparing AVE with shared variance (Fornell \& Larcker,1981; Gerbing \& Anderson, 1992). The smallest $\chi^{2}$ value was $96.09(\mathrm{p}<0.001)$, the smallest square root of Average Variance Extracted (AVE) 
by our measurement model (0.73) is bigger than the largest correlation coefficient $(-0.56)$ among the constructs. Therefore, the discriminant validity was confirmed (Fornell \& Larcker, 1981). Table 3 presents the basic statistics of the constructs and control variables, where the measures for the multi-item scale constructs are the averages of the items that measure the constructs. It also shows the square root of AVE on the diagonal.

Insert Table 3 about here

The descriptive statistics in in Table 3 show that the mean of supplier trust is quite low ( 2.82 on a $0-10$ scale), confirming that suppliers generally do not trust startups. In addition, supplier's trust is negatively correlated with supplier's equity share (-0.29) and qualification of supplier's abilities (-0.56). This suggests that startups offer a higher percentage of equity shares to suppliers to reduce the perceived uncertainty of the startup by the supplier. Startups exert greater effort to evaluate supplier's capabilities when supplier's trust is low. Table 3 also shows that supplier's equity share is positively correlated with supplier's specific investment and qualification of supplier's abilities ( 0.51 and 0.58 respectively); startups offer a high percentage of equity shares to the suppliers whom the startup has exerted greater effort to qualify and who have made larger specific investments in the startup. Finally, supplier involvement is positively related to supplier's specific investment (0.33), supplier's equity share (0.38), and qualification of supplier's abilities (0.39), but negatively related to supplier's trust in the startup.

\section{Hypothesis Testing and Other Results}


Hypothesis Testing. The research hypotheses are tested in a regression analysis on supplier involvement. To ease interpretation of moderating effects, we mean-centered all variables in the regression models.

Insert Table 4 about here

Model 1 only includes the main effects. Model 2 is a full model, which includes the main and the interaction terms. The model comparison F-test shows that Model 2 explains significantly more variance in supplier involvement than Model $1(\mathrm{p}<.05)$; the results reject Model 1. Thus, we focus further discussion on results of Model 2.

The Model 2 results in Table 4 show that both main effects of supplier's specific investment and qualification of supplier's ability are positive and significant $(b=0.18$ and $p<0.01$ for supplier's specific investment; and $b=0.18 \mathrm{p}<0.05$ qualification of supplier's ability); holding supplier's equity share and supplier trust at mean levels, increases in supplier's specific investment or/and qualification of supplier's ability lead to increases in supplier involvement. The interaction terms of supplier's equity share with supplier's specific investment and qualification of supplier's ability are also positive significant ( $b=0.02$ and $p<0.05$ for both). Therefore, Hypotheses $1 \mathrm{a}$ and $1 \mathrm{~b}$ (supplier's equity share positively moderating the positive relationships between supplier's specific investment and supplier's involvement and between qualification of supplier's ability and supplier involvement) are supported by our data. The interaction terms of supplier's trust with supplier's specific investment and qualification of supplier's ability are also positive and significant $(\mathrm{b}=0.08$ and $\mathrm{p}<0.01$ for supplier's investment; 
$b=0.04$ and $p<0.10$ for qualification of supplier's ability), supporting Hypothesis $2 b$ (supplier's trust positively moderating the relationship between qualification of supplier's ability and supplier involvement), but not Hypothesis 2a (supplier's trust negatively moderating the positive relationship between supplier's specific investment and supplier involvement).

The Model 2 results also reveal empirical impacts of the moderators. First, every one percent increase in supplier's equity share leads to a 0.02 unit increase in the coefficients (marginal effect) of supplier's specific investment and of qualification of supplier's abilities. Second, a one-unit increase in supplier's trust leads to a 0.08 unit increase in the coefficient (marginal effect) for supplier's specific investment. Finally, a one unit increase in supplier's trust leads to a 0.04 unit increase in the coefficient of qualification of supplier's abilities.

Insert figures $2 \mathrm{a}, 2 \mathrm{~b}, 3 \mathrm{a}$, and $3 \mathrm{~b}$ about here

A deeper understanding of the moderating effects of supplier's equity share and supplier trust is gained through Figures 2a, 2b, 3a, and 3b, which show the main effects of supplier's specific investment and qualification of supplier's ability on supplier involvement for different levels of the moderator variables. Figures $2 \mathrm{a}$ and $2 \mathrm{~b}$ depict the moderating effects of supplier's equity share. Figure 2 a shows that an increase in supplier's specific investment results in an increase of supplier involvement only when supplier's equity share is at average or above average levels (the average level of supplier equity share was $10.32 \%$ in our sample). When supplier's equity share is lower than $10.32 \%$, suppliers' specific investment has no significant effect on supplier involvement. Similarly, Figure $2 b$ indicates that an increase in the qualification supplier's ability results in increased supplier involvement only when supplier's equity share is at 
SUPPLIER INVOLVEMENT IN STARTUP INNOVATION

average or above average level; otherwise, qualification of supplier's ability has no significant effect on supplier involvement.

Figures $3 \mathrm{a}$ and $3 \mathrm{~b}$ demonstrate the moderating effects of supplier's trust in the startup. Figure 3a demonstrates that an increase in supplier's specific invest leads to increased supplier involvement only when supplier's trust is at average or above average levels (the average level of supplier's trust was 2.82 on a $0-10$ scale in our sample). When supplier's trust is lower than 2.82 average, it has no significant effect on supplier involvement. Also, in Figure 3b, an increase in qualification of supplier's ability leads to increased supplier involvement only when supplier's trust is higher than average (2.82), otherwise, qualification of supplier's ability has no impact.

Other Results. Finally, we also examined the main effects of the moderators (not reported in the tables and figures). When supplier's specific investment is at below mean level, supplier's trust and equity share have no significant effects on supplier involvement. When supplier's specific investment is at mean level (6.17), supplier's equity share has a significant positive impact on supplier involvement, but supplier's trust has no significant impact. When supplier's specific investment is higher than mean level (6.6 or higher), both supplier equity share and supplier trust have significant positive effects on supplier involvement. In addition, supplier's equity share and trust have significant positive effects on supplier involvement only when qualification of supplier's ability is at mean or above mean levels.

Although, we do not hypothesize a relationship between supplier involvement and performance as it has been well established in the literature, we performed OLS regression analysis of this relationship in our empirical analysis using the same set of variables as those in supplier involvement regressions. The results show that supplier involvement has a positive 
significant effect on three-year average growth margin $(b=8.30 ; p<.01)$ as well as a positive significant effect on three-year average sales growth $(b=82.88 ; p<.01)$.

\section{DISCUSSION AND CONCLUSIONS}

\section{Discussion and Theoretical Implications}

This study extends the literature on supplier involvement in innovation to a startup setting. More specifically, by building on a TCE contingency framework we examine how supplier trust and supplier's equity share moderate the impact of partner specific investment (asset-specific investments by the supplier and qualification of the supplier's abilities by the startup) as drivers of supplier involvement with startups. Our data show that supplier involvement is pivotal to product innovation performance, which is consistent with the prior literature on supplier involvement (Van Echtelt et al., 2008; Wynstra et al., 2001, 2003). Interestingly, our results further reveal that supplier's specific investment and startup's effort in qualification of supplier's ability lead to higher levels of supplier involvement only when supplier's equity share and supplier's trust are sufficiently high. As such, the findings of our

study expand the extant supplier involvement literature by demonstrating that supplier involvement in startup settings is a distinctive process that is due to startup-specific contingencies.

More specifically, our results reveal that offering a larger equity share to the supplier strengthens the effects of supplier's specific investments and qualification of supplier's abilities on supplier involvement. The positive moderating effect of equity share on the relationship between supplier's specific investment and supplier involvement confirms our expectations: A larger stake in the startup's equity stimulates supplier's motivation to tailor its investments in the best interests of the startup, facilitating the impact of supplier's specific investment on its 
involvement in the startup's NPD effort. In addition, the positive moderating effect of supplier's equity share on the relationship between qualification of supplier's abilities and supplier involvement suggests that offering equity encourages well-qualified suppliers to exert more effort in the startup's innovation process by better integrating its technologies, skills, and resources with the startup's resources, leading to higher supplier involvement. These positive moderating effects of equity share demonstrate that offering equity is an effective means to involve the supplier, through facilitating supplier's specific investments and qualification of supplier's abilities. These results imply that startups can choose effective means that suit their specific situation. They reveal that these means (i.e., equity share) must not necessarily be of high present value to attract suppliers, but rather that it is more important that they reflect the potential for a long-term positive horizon.

In addition, our results show a positive moderating effect of supplier's trust on the relationships between supplier's specific investments and supplier involvement and between qualification of supplier's abilities and supplier involvement. This signifies that supplier's trust in the startup leverages the effects of supplier's specific investments and qualification of supplier's ability on supplier involvement. This implies that the startup needs to take into account supplier's trust as an important contingency, which could enhance the effectiveness of formal governance mechanisms on supplier involvement. Fostering trust in the supplier typically requires a longterm perspective. It takes much time and many transactions to build desirable levels of trust. Once the supplier highly trusts the startup, it will be more willing to take risks and to develop stronger bonds with the startup. Our findings are consistent with the stream of research that advocates the complementary role of trust (Wathne \& Heide, 2000; Heide, 2003) and therefore fuel the debate as to whether trust has a substituting or complementing role in startup settings. 
The moderating effects of equity share and supplier trust indicate that the startup should consider not only increasing the reward of the prospective supplier (through increasing equity share), but also decreasing the supplier's perceived risk through time (by putting emphasis on building the trust of the supplier). We should also note here that the startup's actions (such as increasing supplier equity) may increase supplier involvement, which increase the importance of the supplier to the startup; however, the reverse is not guaranteed. That is, if the supplier is very large relative to the startup, the startup possibly will not become that important to that supplier no matter the type of means used to increase its involvement! This suggests the more complex and multidimensional nature of the relationship between the moderating effects (supplier equity and supplier trust) and supplier involvement. Future research should therefore take a more pronounced multidimensional perspective and further increase our understanding of the contingencies that facilitate or impede supplier involvement in startup's innovation activities.

\section{Implications for Management}

Our findings suggest that startups must adopt a long-term strategy to get and keep suppliers involved. A strong long-term orientation influences supplier involvement, and helps the startup reap the benefits from a well-planned risk-reward strategy. Supplier trust is controllable by the startup and is important in establishing a stable, long-term relationship. In fact, the average level of trust across all dyads in the sample was rather low (2.82 on a $0-10$ scale). There is thus still much opportunity to continue to build trust to further improve supplier involvement. Also, a negative correlation was found between trust and qualification of supplier's abilities $(-0.56)$ in our sample: the lower the levels of trust, the more intensive was the supplier qualification procedure by the startup. It is possible the startups could take the qualification procedure as an opportunity to gain and build the trust of their suppliers. The startup should try to develop a 
culture of trust by improving the communication process between itself and the supplier. Throughout the NPD process, the startup should exert efforts in enhancing the quality of information exchange with the supplier in terms of accuracy, timeliness, and adequacy, and focusing on behavioral norms and expectations rather than contractual obligations (Bstieler, 2006).

\section{Limitations and Future Research Directions}

In this research study, we have strived to develop an effective yet parsimonious model of supplier involvement. Thus, one limitation is that there may be other contingencies which we had not taken into account. These may include expectations of continuity (Heide \& John, 1990), attractiveness of product line (Anderson, 1985), bureaucratic structure (John, 1984), and monitoring (Stump \& Heide, 1996), all of which can be addressed in future studies.

Second, we did not propose any research hypotheses concerning the effect of supplier power in this model, though our findings suggest that supplier power may have a complex relationship with supplier involvement. Specifically, increased supplier power seems to be related to lower supplier involvement, which suggests that the more powerful the supplier is, the less likely the startup will be able to reap the rewards obtained from the partnership. Further studies can explore the dynamic relationships between supplier power, supplier involvement, and the various antecedents in this model.

Third, our study may suffer sample selection bias. This study relied on the startup to identify a major supplier. Although this selection is consistent with prior literature on supplier involvement, it may be biased because the startup is likely to identify more successful partners. In addition, because our sample did not include the startups that "died" before our survey, our study may suffer a survivor bias. 
In addition, this study has suggested several possible directions for future research. For example, we identified possible motivations for the supplier to enter into a relationship with the startup, noting that this may include asset leveraging in order to reduce costs, as well as financial rewards such as increased equity share. Further work could investigate the relative importance of these factors and how they interact with perceived risk. A startup may offer the supplier the possibility to increase output and reduce costs per unit together with high profitability from equity sharing, but this needs to be offset against the perceived risk of working with an unknown quantity (since an established customer could also offer the benefit of increased output and lower unit costs). Finally, it may be interesting to explore the dynamics of trust, and its impact on supplier involvement through time. That is, gaining supplier trust at the outset of a relationship may be an outcome that arises from the formal procedure of supplier qualification; however, trust can build further through time as the relationship proceeds, and may itself become an informal mechanism to further encourage supplier involvement.

\section{REFERENCES}

Amstrong, J. S. \& T. S. Overton. (1977). Estimating nonresponse bias in mail survey. Journal of Marketing Research, 14, 396-402.

Anderson, E. (1985). The salesperson as outside agent or employee: a transaction cost analysis. Marketing Science 4(Summer), 234-254.

Anderson, E. (1988a). Transaction costs as determinants of opportunism in integrated and independent sales forces. Journal of Economic Behavior and Organization 9(May), 247-64.

Anderson, E. (1988b). Strategic implications of Darwinian economics for selling efficiency and choice of integrated or independent sales forces. Management Science 34, 599-618. 
SUPPLIER INVOLVEMENT IN STARTUP INNOVATION

Anderson, C. and J. A. Narus. (1990). A model of distributor firm and manufacturer firm working partnership. Journal of Marketing 54(January), 42-58.

Argyres, N. S., J. Bercovitz, and K. J. Mayer. (2007). Complementarity and evolution of contractual provisions: An empirical study of IT services contracts. Organization Science 18(1), 3-19.

Artz, K. W. and T. H. Brush. (2000). Asset specificity, uncertainty and relational norms: An examination of coordination costs in collaborative strategic alliances. Journal of Economic Behavior and Organization 41, 337-362.

Ayers, D., R. Dahlstrom, and S. J. Skinner. (1997). An exploratory investigation of organizational antecedents to new product success. Journal of Marketing Research 34(1), 107-116.

Blodgett, L. L. (1991). Partner contributions as predictors of equity share in international joint ventures. Journal of International Business Studies 22(March), 63-78.

Blodgett, L. L. (1992). Factors in the instability of international joint ventures: an event history analysis. Strategic Management Journal 13(6), 475-481.

Bradach, J. L. and R. G. Eccles. (1989). Price, authority, and trust: From ideal types to plural forms. In Annual Review of Sociology, Scott WR, Blake, J (Eds.). Annual Reviews, Palo Alto, CA. Vol. 15, 97-118.

Buskirk, B., and M. Lavik. (2004). Entrepreneurial Marketing: Real Stories \& Survival Strategies. Thompson South-Western Publishing.

Casson, M. (1991). The economics of business culture: game theory, transaction costs, and economic performance. Clarendon Press: Oxford. 
Chesbrough, H. W. (2003). The era of open innovation. MIT Sloan Management Review 44(3), $35-41$

Corts, K. S., and J. Singh. (2004). The effect of repeated interaction on contract choice: evidence from offshore drilling. Journal of Law, Economics \& Organization 20(1), 230-260.

Cousins, P. (2005). The alignment of appropriate firm and supply strategies for competitive advantage. International Journal of Operations \& Production Management, 25(5), 403-428.

Cousins, P. D. and B. Lawson. (2007). Sourcing strategy, supplier relationships and firm performance: An empirical investigation of UK organizations. British Journal of Management 18(2), 123-137.

David, R. J., and S. K. Han. (2004). A systematic assessment of the empirical support for transaction cost economics. Strategic Management Journal 25, 39-58.

Das, T. K., and B. S. Teng. (1998). Between trust and control: developing confidence in partner cooperation in alliances. Academy of Management Review 23(3), 491-512.

Dushnitsky, G. and M. J. Lenox. (2005). When do firms undertake R\&D by investing in startups? Strategic Management Journal 26(10), 947-965.

Dyer, J. H. (1997). Effective interfirm collaboration: how firms minimize transaction costs and maximize transaction value. Strategic Management Journal 18(7), 535-556.

Dyer, J. H. and H. Singh. (1998). The relational view: cooperative strategy and sources of interorganizational competitive advantage. Academy of Management Review 23(4), 660-679.

Ebers, M. and L. Oerlemans. (2016). The variety of governance structures beyond market and hierarchy. Journal of Management 42(6), 1491-1529.

Echambadi, R. and D. Hess. (2007). Mean-centering does not alleviate collinearity problems in moderated multiple regression models. Marketing Science 26(3), 438-445. 
Fornell, C. and D. F. Larcker. (1981). Evaluating structural equation models with unobservable observation variables and measurement error. Journal of Marketing Research 48, 39-50.

Geringer, J. M. and L. Hebert. (1989). Control and performance of international joint ventures. Journal of International Business Studies 20(2), 235-254.

Geyskens I, J.-B. E. Steenkamp, and N. Kumar. (2006). Make, buy, or ally: A meta-analysis of transaction cost theory. Academy of Management Journal 49(3), 519-543.

Gerbing, D. W., and J. C. Anderson. (1992). Monte Carlo evaluations of goodness of fit indices for structural equation models. Sociological Methods and Research 21(2), 132-60.

Gilbert, B. A., P. P. McDougall, and D. B. Audretsch. (2006). New venture growth: a review and extension. Journal of Management, 32(6), 926-950.

Grover, V. and M. K. Malhotra. (1995). Transaction cost framework in operations and supply chain management research: Theory and measurement. Journal of Operations Management, 21(4), 457-473.

Gulati, R. (1995). Does familiarity breed trust? The implication of repeated ties for contractual choice in alliances. Academy of Management Journal 38(1), 85-112.

Gulati, R. and J. A. Nickerson. (2008). Interorganizational trust, governance choice, and exchange performance. Organization Science 19(5), 688-708.

Harland, C. M. (1996). Supply chain management: Relationships, chains and networks. British Journal of Management 7(S1), S63-S80.

Heide, J. B. (1994). Interorganizational governance in marketing channels. Journal of Marketing 58(1), 71-85.

Heide, J. B. (2003). Plural governance in industrial purchasing. Journal of Marketing 67(4), 1829. 
SUPPLIER INVOLVEMENT IN STARTUP INNOVATION

Heide, J. B. and G. John. (1990). Alliances in industrial purchasing: The determinants of joint action in buyer-supplier relationship. Journal of Marketing Research 27(February), 24-36.

Heide, J. B. and A. S. Miner. (1992). The shadow of the future: Effects of anticipated interaction and frequency of contact on buyer-seller cooperation Academy of Management Journal 35, $265-291$.

Hoegl, M. and S. M. Wagner. (2005). Buyer-supplier collaboration in product development projects, Journal of Management, 31(4), 530-548.

Huston, L. and N. Sakkab. (2006). Connect and develop: Inside Procter \& Gamble's new model for innovation. Harvard Business Review 84(3), 58-66.

Jaccard, J. J., R. Turrisi, and C. K. Wan. (1990). Interaction Effects in Multiple Regression. Sage Publications: Newbury Park.

Jean, R. B., R. R. Sinkovics, and T. P. Hiebaum. (2014). The effect of supplier involvement and knowledge protection on product innovation in customer-supplier relationships: A study of global automatic suppliers in China. Journal of Product Innovation Management, 31(1), 98113.

Jensen, R. and M. Thursby. (2001). Proofs and prototypes for sale: The licensing of university inventions. American Economic Review 91(1), 240-259.

John, G. (1984). An empirical investigation of some antecedents of opportunism in a marketing channel. Journal of Marketing Research 21(August), 278-289.

Kalnins, A. and K. G. Mayer (2004). Relationships and hybrid contracts: An analysis of contract choice in information technology. Journal of Law, Economics \& Organization 20(1), 207229. 
Klein, B., R. G. Crawford, and A. A. Alchian. (1978). Vertical integration, appropriable rents and the competitive contracting process. Journal of Law \& Economics 21(2), 297-326.

Korsgaard, M.A., H. H. Brower, and S. W. Lester. (2015). It isn’t always mutual: a critical review of dyadic trust. Journal of Management, 41(1), 47-70.

Larson, A. (1992). Network dyads in entrepreneurial settings: A study of the governance of exchange relationships. Administrative Science Quarterly, 37(1), 76-104.

Le Breton-Miller, I., and D. Miller. (2006). Why do some family businesses out-compete? Governance, long-term orientations, and sustainable capability. EntrepreneurshipTheory \& Practice, 30 (November), 731-746.

Lecraw, D. J. (1984). Bargaining power, ownership, and profitability of transnational corporations in developing countries. Journal of International Business Studies 15(1), 27-43.

Lee, H. L. (2002). Aligning supply chain with product uncertainties. California Management Review 44(3), 104-119.

Leiblein, M. J. (2003). The choice of organizational governance form and performance: prediction from transaction cost, resource-based, and real options theories. Journal of Management 29(6), 937-961.

Liu, Y., Y. Luo, and T. Liu. (2009). Governing buyer-supplier relationships through transactional and relational mechanisms: Evidence from China. Journal of Operations Management 27, 294-309.

Lodish L., H. L. Morgan, and A. Kallianpur. (2001). Entrepreneurial Marketing, New York, John Wiley and Sons.

Lumineau, F. (2017). How contracts influence trust and distrust. Journal of Management 43(5), 1553-1577. 
Lumpkin, G. T. and K. H. Brigham. (2011). Long-term orientation and intertemporal choice in family firms. Entrepreneurship Theory \& Practice 35 (November), 1149 -1169.

Luo, Y. (2002). Contract, cooperation, and performance in international joint ventures. Strategic Management Journal 23(10), 903-919.

Marion, T.J., J. H. Friar, and T. W. Simpson. (2012). New product development practices and early-stage firms: Two in-depth case studies. Journal of Product Innovation Management, 29(4), 639-654.

Martines, R. J. and M. T. Dacin. (1999). Effeiciency motives and normative forces: combining transactions costs and institutional logic. Journal of Management, 25(1), 75-96.

Mayer, K. J. and N. S. Argyres. (2004). Learning to contract: Evidence from the personal computer industry. Organization Science 15(4), 394-410.

Mesquita, L. F., J. Anand, and T. H. Brush. (2008). Comparing the resource-based and relational views: Knowledge transfer and spillover in vertical alliances. Strategic Management Journal 29(September), 913-941

Mjoen, H. and S. Tallman. (1997). Control and performance in international joint ventures. Organization Science 8(May-June), 257-274.

Moorman, C., G. Zaltman, and R. Deshpande. (1992). Relationships between providers and users of market research: The dynamics of trust within and between organizations. Journal of Marketing Research 29(3), 314-328.

Morgan, R. M. and S. D. Hunt. (1994). The commitment-trust theory of relationship marketing. Journal of Marketing 58(3), 20-38.

Narver, J. C. and S. F. Slater. (1990). The effect of a market orientation on business profitability. Journal of Marketing 54(October), 20-35. 
Noorderhaven, N. G. (1994). Transaction cost analysis and the explanation of hybrid vertical interfirm relations. Review of Political Economy 6, 19-36.

Nooteboom, B, H. Berger, and N. G. Noorderhaven. (1997). Effects of trust and governance on relational risk. Academy of Management Journal 40, 308-338.

Oxley, J. E. (1997). Appropriability hazards and governance in strategic alliances: A transaction cost approach. Journal of Law, Economics, and Organization 13, 387-409.

Payne, G.T., J. L. Davis, C. B. Moore, and R. G. Bell. (2009). The deal structuring stage of the venture capitalist decision-making process: Exploring confidence and control. Journal of Small Business Management 2, 154-179.

Petersen, K. J., R. B. Handfield, and G. L. Ragatz. (2005). Supplier integration into new product development: Coordinating product, process, and supply chain design. Journal of Operations Management 23(3-4), 371-388.

Potter, A. and B. Lawson. (2013). Help or hindrance? Causal ambiguity and supplier involvement in new product development teams. Journal of Product Innovation Management 30(4), 794-808.

Prahinski, C. and W. C. Benton. (2004). Supplier evaluations: communication strategies to improve supplier performance. Journal of Operations Management 22(1), 39-62.

Provan, K. (1993). Embeddedness, interdependence, and opportunism in organizational supplierbuyer networks. Journal of Management 19(4), 841-856.

Read, S., N. Dew, S. D. Sarasvathy, M. Song, and R. Wiltbank. (2009). Marketing under uncertainty: The logic of an effectual approach. Journal of Marketing 73(May), 1-18.

Sapienza, H. and M. Korsgaard. (1996). Procedural justice in entrepreneur-investor relations. Academy of Management Journal 39(3), 544-574. 
Scarbrough, H., J. Swan, K. Amaeshi, and T. Briggs. (2013). Exploring the role of trust in the deal-making process for early-stage technology ventures. Entrepreneurship Theory \& Practice 37 (September), 1203-1228.

Schepker, D. J., W. Oh, A. Martynov, and L Poppo. (2004). The many futures of contracts: moving beyond structure and safeguarding to coordination and adaption. Journal of Management 40(1), 193-225.

Seabright, M. A., D. A. Levinthal, and M. Fichman. (1992). Role of individual attachments in the dissolution of interorganizational relationships. Academy of Management Journal 35(1), $122-150$.

Shane, S. and D. Cable. (2002). Network ties, reputation, and the financing of new ventures. Management Science 48(3), 364-381.

Shepherd, D. A., E. J. Duglas, and M. Shanley. (2000). New venture survival: ignorance, external shocks, and risk reduction strategies, Journal of Business Venturing 15(5-6), 393410.

Sohn, J. H. D. (1994). Social knowledge as a control system: A proposition and evidence form the Japanese FDI behavior. Journal of International Business Studies 25(2), 295-324.

Song, M. and C. A. Di Benedetto. (2008). Supplier's involvement and success of radical new product development in new ventures. Journal of Operations Management 26(1), 1-22.

Spekman, R. E. (1988). Strategic supplier selection: Understanding long-term buyer relationships. Business Horizons 31(4), 75-81.

Squire, B., P. D. Cousins, and S. Brown. (2009). Cooperation and knowledge transfer within buyer-supplier relationships: The moderating properties of trust, relationship duration and supplier performance. British Journal of Management 20(4), 461-477. 
SUPPLIER INVOLVEMENT IN STARTUP INNOVATION

Stump, R. L. and J. B. Heide. (1996). Controlling supplier opportunism in industrial relationships. Journal of Marketing Research 33(4), 431-441.

Uzzi, B. (1996). The sources and consequences of embeddedness for the economic performance of organizations: The network effect. American Sociological Review 61, 674-698.

Van Echtelt, F. E. A., F. Wynstra, A. J. Van Weele, and G. Duysters. (2008). Managing supplier involvement in new product development: A multiple case study. Journal of Product Innovation Management 25(2), 180-201.

Wathne, K. H., H. Biong, and J. B. Heide. (2001). Choice of supplier in embedded markets: Relationship and marketing program effects. Journal of Marketing 65(2), 54-66.

Wathne, K. H. and J. B. Heide. (2000). Opportunism in interfirm relationships: Forms, outcomes, and solutions. Journal of Marketing 64(4), 36-51.

Welter, F. (2012). All you need is trust? A critical review of the trust and entrepreneurship literature. International Small Business Journal 30(3), 193-212.

Williamson, O. E. (1983). Credible commitments: Using hostages to support exchange. American Economic Review 73(4), 519-535.

Williamson, O. E. (1985). The Economic Institutions of Capitalism. Free Press: New York. Wynstra, J. Y. F., A. J. van Weele, and M. Weggeman. (2001). Managing supplier involvement in product development: Three critical issues. European Management Journal 19(2), 157167.

Wynstra, J. Y. F., M. Weggeman, and A. J. van Weele. (2003). Exploring purchasing integration in product development. Industrial Marketing Management 32(1), 69-83. 
SUPPLIER INVOLVEMENT IN STARTUP INNOVATION

Zaheer, A. and N. Venkatraman. (1995). Relational governance as an interorganizational strategy: An empirical test of the role of trust in economic exchange. Strategic Management Journal 16, 373-392.

Zajac, E.J. and C. P. Olsen. (1993). From transaction cost to transactional value analysis: Implications for the study of interorganizational strategies. Journal of Management Studies $30(1), 131-145$.

Zenz, G. J. (1994). Purchasing and the Management of Materials. John Wiley \& Sons: New York.

Zhong, W., C. Su, J. Peng, and Z. Yang. (2017). Trust in international relationships: A metaanalytic integration. Journal of Management 43(4), 1050-1075. 


\section{TABLE 1 STUDY MEASURES}

\begin{tabular}{|c|c|}
\hline Variable & Measurements \\
\hline $\begin{array}{l}\text { Supplier's Specific } \\
\text { Investment } \\
\text { (SSINV) } \\
(\text { Cronbach alpha }=0.90)\end{array}$ & $\begin{array}{l}\text { (11 point scale: } 0=\text { strongly disagree; } 10=\text { strongly agree) } \\
\text { SSINV1: Our production system has been tailored to producing the items being sold to this firm. } \\
\text { SSINV2: We have spent significant resources to ensure that the specifications of our supplies for this } \\
\text { product fit well with this firm's production capabilities. } \\
\text { SSINV3: Gearing up to deal with this firm on this product requires highly specialized tools and } \\
\text { equipment. } \\
\text { SSINV4: his firm has some unusual technological standards for this item, which have required } \\
\text { extensive adaptation by our production system. } \\
\text { SSINV5: Most of the training we have undertaken relative to this firm's requirements for this product } \\
\text { can be easily adapted for use with another customer. (R) }\end{array}$ \\
\hline $\begin{array}{l}\text { Supplier's Equity } \\
\text { Share }(\%) \\
\text { (SEQT) }\end{array}$ & $\begin{array}{l}\text { Did you offer this major supplier any equity shares of your company? If so, how much does } \\
\text { this supplier own (\% of total equity shares)? }\end{array}$ \\
\hline $\begin{array}{l}\text { Qualification of } \\
\text { Supplier's Abilities } \\
\text { (QSAB) } \\
(\text { Cronbach alpha }=0.92)\end{array}$ & $\begin{array}{l}\text { What was the level of this firm's efforts in evaluating supplier's skills in the following } \\
\text { areas? (11 point scale: } 0=\text { no qualification; } 10=\text { extensive qualification) } \\
\text { QSAB1: Technical capability } \\
\text { QSAB2: Compatibility of production processes } \\
\text { QSAB3: Product quality } \\
\text { QSAB4: Financial strength } \\
\text { QSAB5: Delivery capability }\end{array}$ \\
\hline $\begin{array}{l}\text { Supplier's Trust } \\
\text { (STRST) } \\
(\text { Cronbach alpha }=0.82)\end{array}$ & $\begin{array}{l}\text { (11 point scale: } 0=\text { strongly disagree; } 10=\text { strongly agree) } \\
\text { STRST1: We trust this company to tell us what the customers really want, with high degree of } \\
\text { accuracy. } \\
\text { STRST2: The level of trust our company has in its working relationship with this company is very } \\
\text { high. } \\
\text { STRST3: In our relationship, this company can be counted on to do what is right. }\end{array}$ \\
\hline $\begin{array}{l}\text { Level of Supplier } \\
\text { involvement } \\
\text { (SINVL) } \\
(\text { Cronbach alpha=0.73) }\end{array}$ & $\begin{array}{l}\text { To what extent was this supplier involved in the following stages of product development } \\
\text { process? (11-point scale: } 0=\text { no involvement; } 10=\text { extensive involvement); (note: } \\
\text { Involvement refers to the level of information sharing, coordination, and joint involvement } \\
\text { in performing specific activities). } \\
\text { SINVL1: Product design } \\
\text { SINVL2: Product testing } \\
\text { SINVL3: Product commercialization }\end{array}$ \\
\hline $\begin{array}{l}\text { Innovation } \\
\text { Performance }\end{array}$ & $\begin{array}{l}\text { Gross Margin }(\mathbf{G M})=(\text { Total Revenue-Total Variable Costs }) / \text { Total Revenue } \\
\text { GM1 = Gross margin for the first year } \\
\text { GM2 = Gross margin for the second year } \\
\text { GM3 = Gross margin for the third year } \\
\text { GM: } 3 \text { Years Average Gross Margin }=(\mathrm{GM} 1+\mathrm{GM} 2+\mathrm{GM} 3) / 3 \\
\text { Sales Growth }(\text { SG) } \\
\text { SG1: Sales growth } 1=(\text { sales in year } 2-\text { sales in year } 1) /(\text { sales in year } 1) \\
\text { SG2: Sales growth } 2=(\text { sales in year } 3-\text { sales in year } 2) /(\text { sales in year } 2) \\
\text { SG: } 2 \text { Years Average Sales Growth }=(\mathrm{SG} 1+\mathrm{SG} 2) / 2\end{array}$ \\
\hline Control variables & 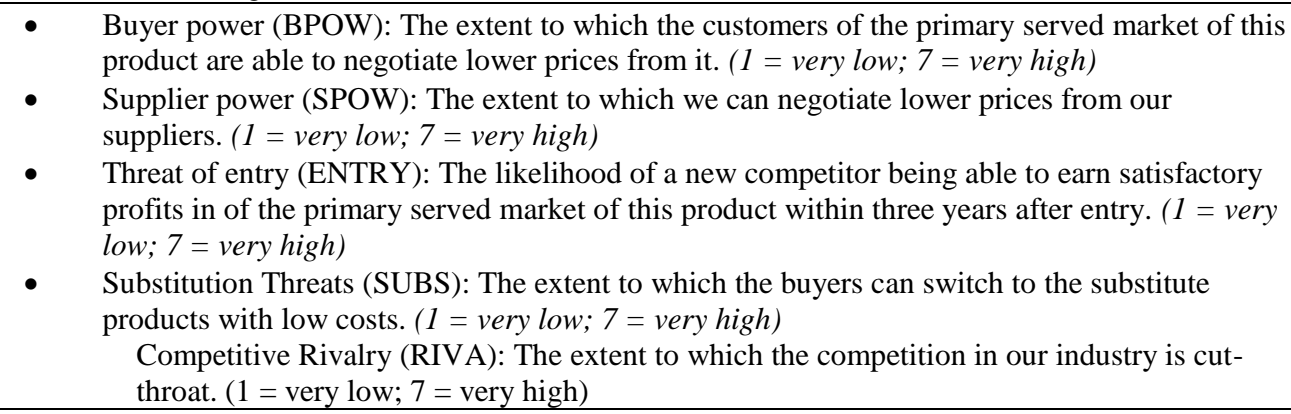 \\
\hline
\end{tabular}


TABLE 2

RESULS OF FACTOR ANALYSIS

\begin{tabular}{lcccc}
\hline & $\begin{array}{c}\text { Qualification } \\
\text { of Supplier's } \\
\text { Abilities } \\
\text { (QSAB) }\end{array}$ & $\begin{array}{c}\text { Supplier's } \\
\text { Specific } \\
\text { Investment } \\
\text { (SSINV) }\end{array}$ & $\begin{array}{c}\text { Supplier's } \\
\text { Trust } \\
\text { (STRST) }\end{array}$ & $\begin{array}{c}\text { Level of } \\
\text { Supplier } \\
\text { involvement } \\
\text { (SINVL) }\end{array}$ \\
\hline Exploratory Factor Analysis: Factor Loadings & & \\
\hline QSAB1 & $\mathbf{0 . 8 7}$ & 0.10 & -0.22 & 0.22 \\
QSAB4 & $\mathbf{0 . 8 7}$ & 0.19 & -0.09 & 0.15 \\
QSAB2 & $\mathbf{0 . 8 2}$ & 0.14 & -0.28 & 0.09 \\
QSAB3 & $\mathbf{0 . 7 8}$ & 0.17 & -0.21 & 0.02 \\
QSAB5 & $\mathbf{0 . 7 3}$ & 0.15 & -0.35 & 0.25 \\
SSINV1 & 0.13 & $\mathbf{0 . 8 9}$ & 0.04 & -0.03 \\
SSINV2 & 0.20 & $\mathbf{0 . 8 4}$ & -0.04 & 0.16 \\
SSINV4 & 0.10 & $\mathbf{0 . 8 2}$ & -0.06 & 0.17 \\
SSINV3 & 0.10 & $\mathbf{0 . 8 1}$ & -0.12 & -0.06 \\
SSINV5 & 0.11 & $\mathbf{0 . 7 8}$ & 0.08 & 0.22 \\
STRST1 & -0.21 & 0.08 & $\mathbf{0 . 8 8}$ & -0.01 \\
STRST2 & -0.30 & -0.10 & $\mathbf{0 . 8 0}$ & 0.14 \\
STRST3 & -0.33 & -0.04 & $\mathbf{0 . 7 3}$ & -0.25 \\
SINVL1 & 0.11 & 0.11 & -0.05 & $\mathbf{0 . 9 5}$ \\
SINVL3 & 0.20 & 0.07 & -0.08 & $\mathbf{0 . 8 7}$ \\
SINVL2 & 0.21 & 0.33 & 0.09 & $\mathbf{0 . 4 1}$ \\
\hline
\end{tabular}

Confirmatory Factor Analysis Model Fitting Indices: $\chi^{2}=217.86$; $d \mathbf{f}=9$; GFI=0.87; CFI=0.93; RMSEA=0.09

Note: See Table 1 for variable coding. $\mathrm{N}=166$ 
TABLE 3

MEANS, STANDARD DEVIATIONS AND CORRELATION MATRIX

\begin{tabular}{|c|c|c|c|c|c|c|c|c|c|c|c|c|}
\hline Variables & GM & SG & SINVL & SSINV & SEQT & QSAB & STRST & BPOW & SPOW & ENTRY & SUBS & RIV \\
\hline \multicolumn{13}{|l|}{3 Years Average Gross } \\
\hline $\operatorname{Margin}(\%)(\mathbf{G M})$ & N/A & & & & & & & & & & & \\
\hline \multicolumn{13}{|l|}{2 Years Average Sales } \\
\hline Growth (\%) (SG) & 0.66 & N/A & & & & & & & & & & \\
\hline \multicolumn{13}{|l|}{ Level of Supplier } \\
\hline involvement (SINVL) & 0.25 & 0.32 & 0.77 & & & & & & & & & \\
\hline \multicolumn{13}{|l|}{ Supplier's Specific } \\
\hline Investment (SSINV) & 0.59 & 0.66 & 0.33 & 0.79 & & & & & & & & \\
\hline \multicolumn{13}{|l|}{ Supplier's Equity } \\
\hline Share(SEQT) & 0.47 & 0.61 & 0.38 & 0.51 & N/A & & & & & & & \\
\hline \multicolumn{13}{|l|}{ Qualification of Supplier's } \\
\hline Abilities (QSAB) & 0.39 & 0.48 & 0.39 & 0.34 & 0.58 & 0.83 & & & & & & \\
\hline Supplier's Trust (STRST) & -0.13 & -0.21 & -0.14 & -0.09 & -0.29 & -0.56 & 0.83 & & & & & \\
\hline Buyer power(BPOW) & -0.14 & -0.17 & -0.04 & -0.01 & -0.08 & -0.04 & 0.00 & N/A & & & & \\
\hline Supplier power(SPOW) & -0.03 & 0.02 & -0.17 & 0.02 & -0.08 & -0.12 & -0.04 & 0.00 & N/A & & & \\
\hline Threat of entry(ENTRY) & 0.11 & -0.03 & -0.03 & 0.08 & 0.07 & 0.09 & 0.02 & -0.05 & -0.10 & N/A & & \\
\hline Threat of substitution(SUBS) & -0.04 & 0.02 & -0.01 & -0.01 & -0.04 & 0.04 & 0.01 & 0.05 & 0.07 & -0.08 & N/A & \\
\hline Rivalry(RIV) & -0.10 & -0.04 & 0.03 & -0.11 & -0.01 & -0.01 & 0.03 & 0.09 & 0.14 & 0.03 & 0.04 & $\mathrm{~N} / \mathrm{A}$ \\
\hline Mean & 38.90 & 276.03 & 3.62 & 6.17 & $10.32 \%$ & 6.34 & 2.82 & 4.10 & 4.02 & 4.01 & 4.04 & 4.08 \\
\hline Standard Deviation & 14.74 & 125.15 & 1.66 & 2.25 & $6.26 \%$ & 2.43 & 2.09 & 1.86 & 1.82 & 1.76 & 1.83 & 1.70 \\
\hline Minimum & 5.76 & 60.00 & 1.33 & 0.80 & $0.00 \%$ & 0.20 & 0.00 & 1.00 & 1.00 & 1.00 & 1.00 & 1.00 \\
\hline Maximum & 63.67 & 564.63 & 38.67 & 10.00 & $20.00 \%$ & 10.00 & 9.67 & 7.00 & 7.00 & 7.00 & 7.00 & 7.00 \\
\hline
\end{tabular}

Note: the numbers on the diagonal in bold italic are square roots of average variance extracted 
TABLE 4

RESULTS OF REGRESSION ANALYSIS

ON SUPPLIER INVOLVEMENT EQUATIONS

\begin{tabular}{|c|c|c|c|c|c|}
\hline \multicolumn{2}{|l|}{ Sample size: $\mathbf{N}=166$} & \multicolumn{2}{|c|}{ Model 1} & \multicolumn{2}{|c|}{ Model 2} \\
\hline Variable & $\begin{array}{l}\text { Hypo- } \\
\text { Thesis }\end{array}$ & $\begin{array}{l}\text { Parameter } \\
\text { Estimate }\end{array}$ & $\begin{array}{l}\text { Standard } \\
\text { Error }\end{array}$ & $\begin{array}{l}\text { Parameter } \\
\text { Estimate }\end{array}$ & $\begin{array}{l}\text { Standard } \\
\text { Error }\end{array}$ \\
\hline Intercept & & 0.07 & 0.55 & 0.00 & 0.53 \\
\hline Supplier's Specific Investment (SSINV) & & $0.15 * *$ & 0.06 & $0.18^{* * *}$ & 0.07 \\
\hline Qualification of Supplier's Abilities (QSAB) & & $0.20 * * *$ & 0.07 & $0.18 * *$ & 0.07 \\
\hline Supplier's Equity Share (\%) (SEQT) & & 0.03 & 0.03 & $0.06^{* *}$ & 0.03 \\
\hline Supplier's Trust (STRST) & & 0.06 & 0.07 & 0.12 & 0.07 \\
\hline SSINV* SEQT & $\mathrm{H} 1 \mathrm{a}$ & & & $0.02 * *$ & 0.01 \\
\hline QSAB*SEQT & $\mathrm{H} 1 \mathrm{~b}$ & & & $0.02 * *$ & 0.01 \\
\hline SSINV*STRST & $\mathrm{H} 2 \mathrm{a}$ & & & $0.08^{* * *}$ & 0.03 \\
\hline QSAB x STRST & $\mathrm{H} 2 \mathrm{~b}$ & & & $0.04 * *$ & 0.02 \\
\hline Buyer power (BPOW) & & 0.00 & 0.06 & -0.01 & 0.06 \\
\hline Supplier power (SPOW) & & $-0.12 *$ & 0.07 & $-0.12 *$ & 0.07 \\
\hline Threat of entry (ENTRY) & & -0.07 & 0.07 & -0.06 & 0.07 \\
\hline Threat of substitution (SUBS) & & -0.02 & 0.07 & -0.02 & 0.06 \\
\hline Rivalry (RIV) & & 0.09 & 0.08 & 0.06 & 0.07 \\
\hline \multicolumn{6}{|l|}{ Industry Dummy Variables: } \\
\hline Audio \& Video & & -0.14 & 0.63 & -0.12 & 0.61 \\
\hline Computer Hardware & & -0.23 & 0.63 & -0.33 & 0.61 \\
\hline \multicolumn{6}{|l|}{ Games, Consumer } \\
\hline Electronics \& Accessories & & -0.22 & 0.64 & -0.44 & 0.62 \\
\hline Digital \& Optical Imaging & & 0.42 & 0.66 & 0.19 & 0.64 \\
\hline \multicolumn{6}{|l|}{ Home Appliances, Home Data Networking, } \\
\hline \&Integrated Home Systems & & -0.23 & 0.64 & -0.28 & 0.63 \\
\hline Software \& Embedded Technologies & & -0.54 & 0.66 & -0.69 & 0.64 \\
\hline Test and Measurement Instruments & & 0.29 & 0.73 & 0.08 & 0.71 \\
\hline Online \& Internet & & 0.48 & 0.68 & 0.19 & 0.67 \\
\hline F-statistic & & $3.30 * * *$ & & $3.66 * * *$ & \\
\hline$R$-Square & & 0.28 & & 0.35 & \\
\hline Adjusted $R$-Square & & 0.19 & & 0.25 & \\
\hline
\end{tabular}

Note: $* * * p<0.01 ; * * p<0.05 ; * \mathrm{p}<0.10$ all hypotheses are evaluated using one-tailed tests 
FIGURE 1

A CONCEPTUAL MODEL FOR STUDYING SUPPLIER'S INVOLVEMENT IN INNOVATION

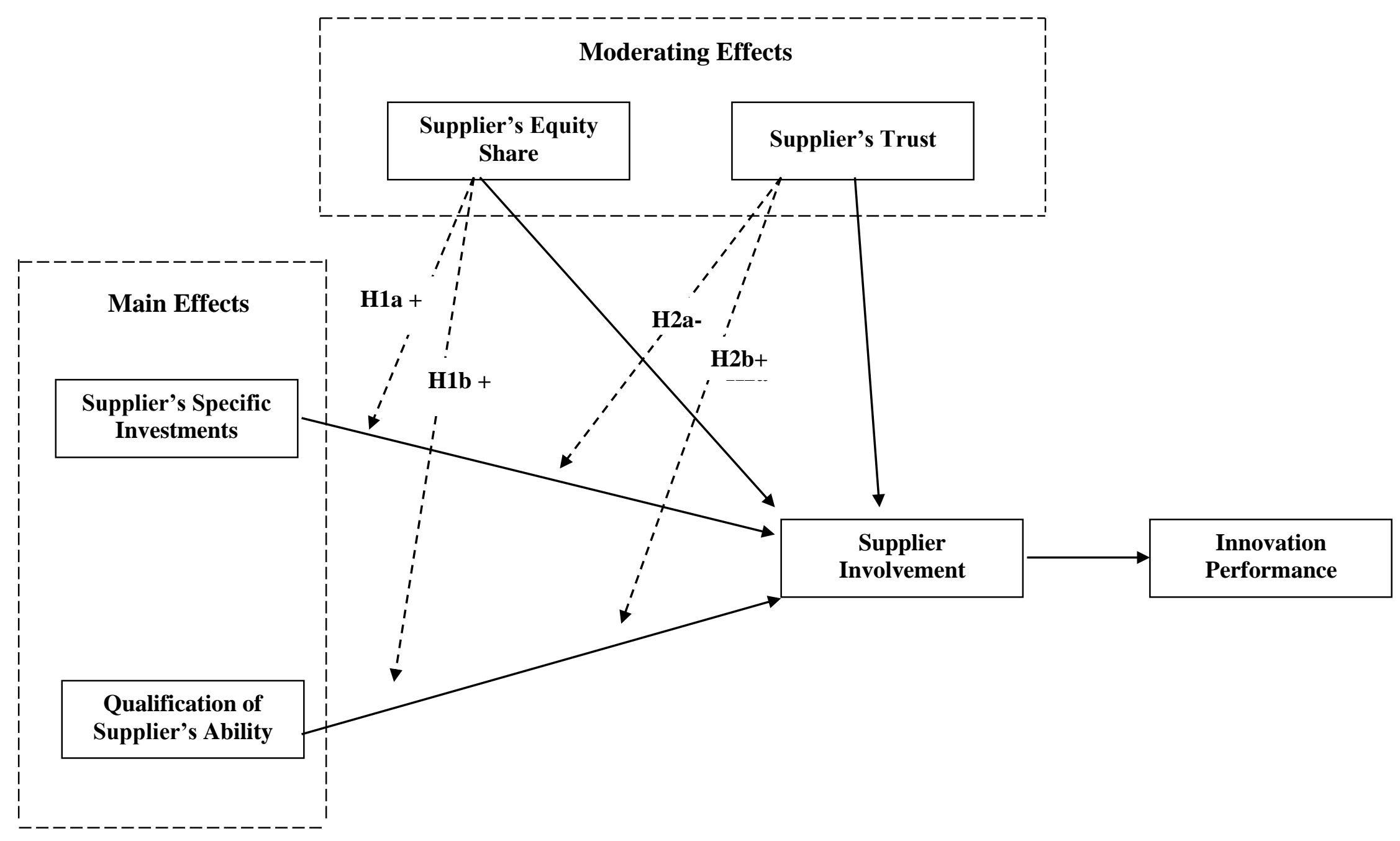

Note: No directional signs are indicated for $\mathrm{H} 2 \mathrm{a}$ or $\mathrm{H} 2 \mathrm{~b}$ since we specified competing hypotheses in these two cases. 
FIGURE 2a.

\section{MARGINAL EFFECT OF SUPPLIER'S SPECIFIC INVESTMENT} AT DIFFERENT LEVELS OF SUPPLIER'S EQUITY SHARE

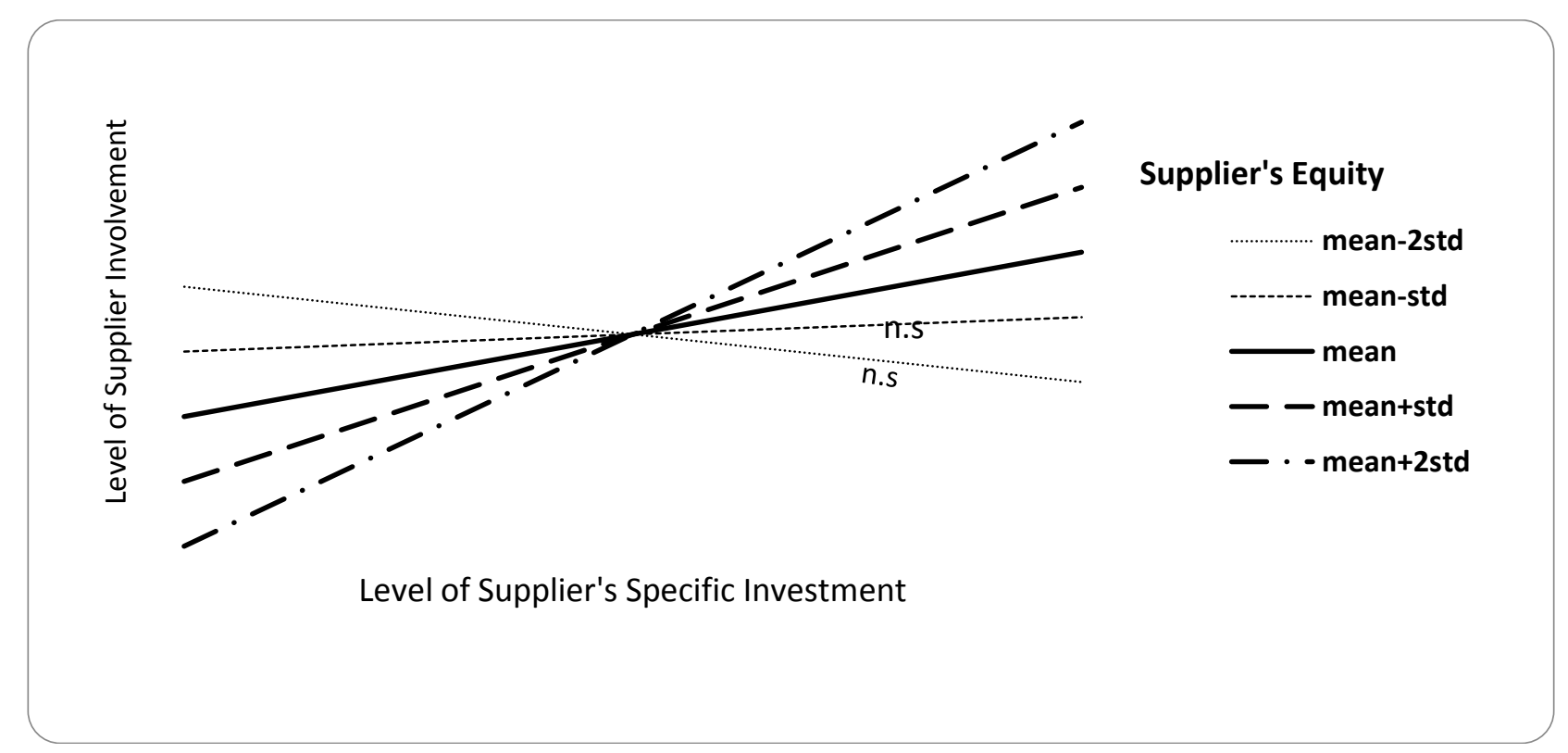

Note: mean-2std = mean level of supplier equity share minus two standard deviations, others interpreted similarly.

\section{FIGURE 2b.}

MARGINAL EFFECT OF QUALIFICATION OF SUPPLIER'S ABILITY AT DIFFERENT LEVELS OF SUPPLIER'S EQUITY SHARE

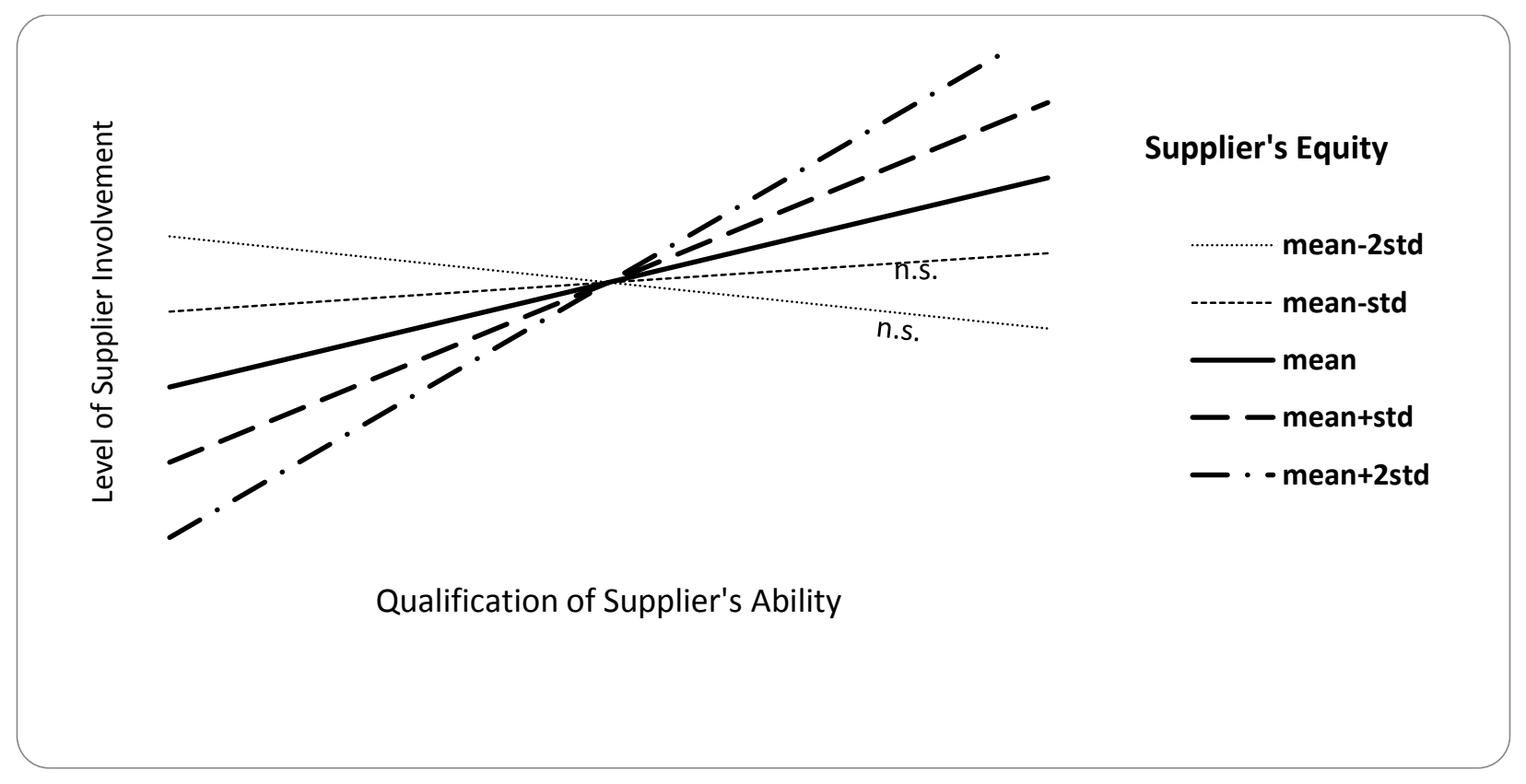


FIGURE 3a.

MARGINAL EFFECT OF SUPPLIER'S SPECIFIC INVESTMENT AT DIFFERENT LEVELS OF SUPPLIER'S TRUST

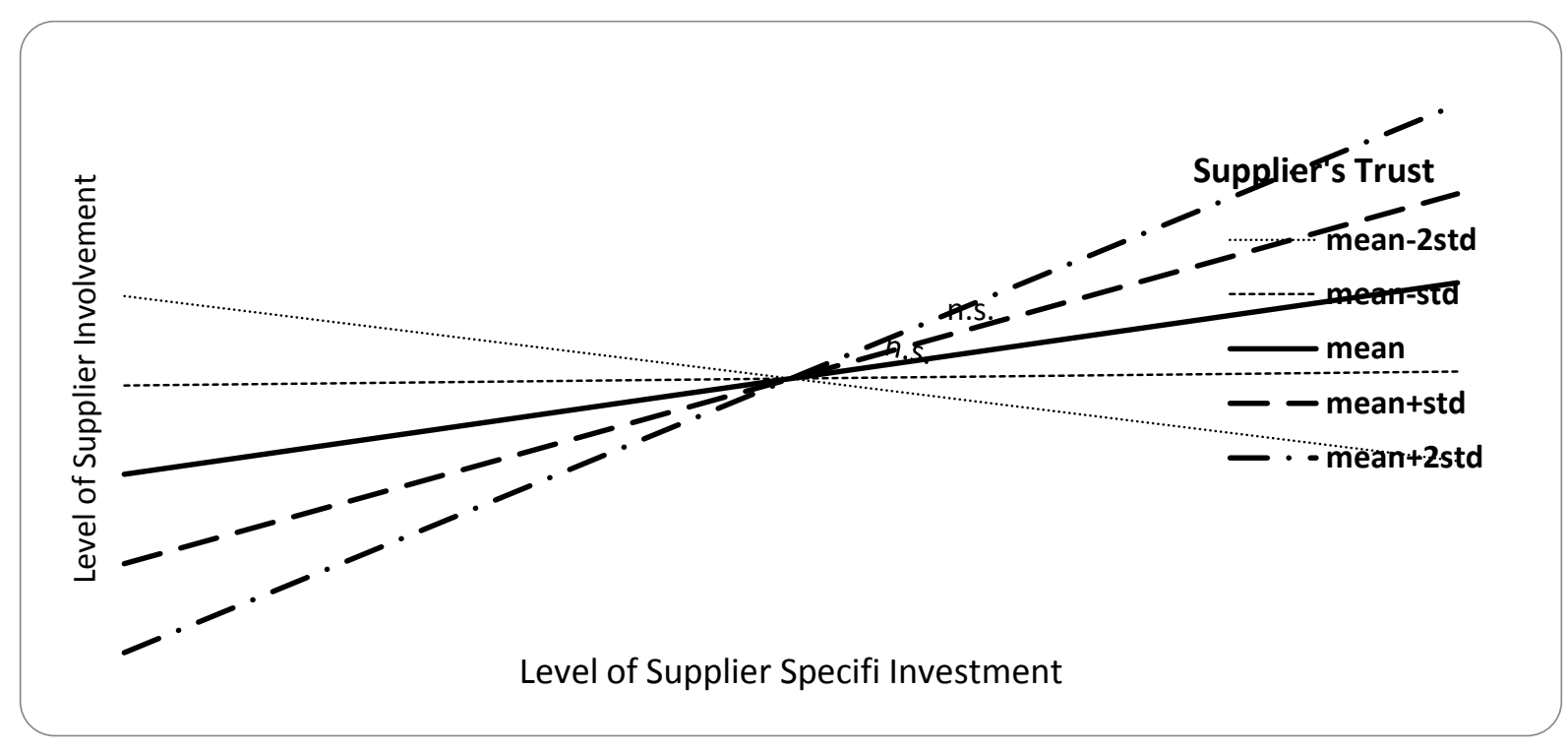

FIGURE 3b.

MARGINAL EFFECT OF QUALIFICATION OF SUPPLIER'S ABILITY AT DIFFERENT LEVELS OF SUPPLIER'S TRUST

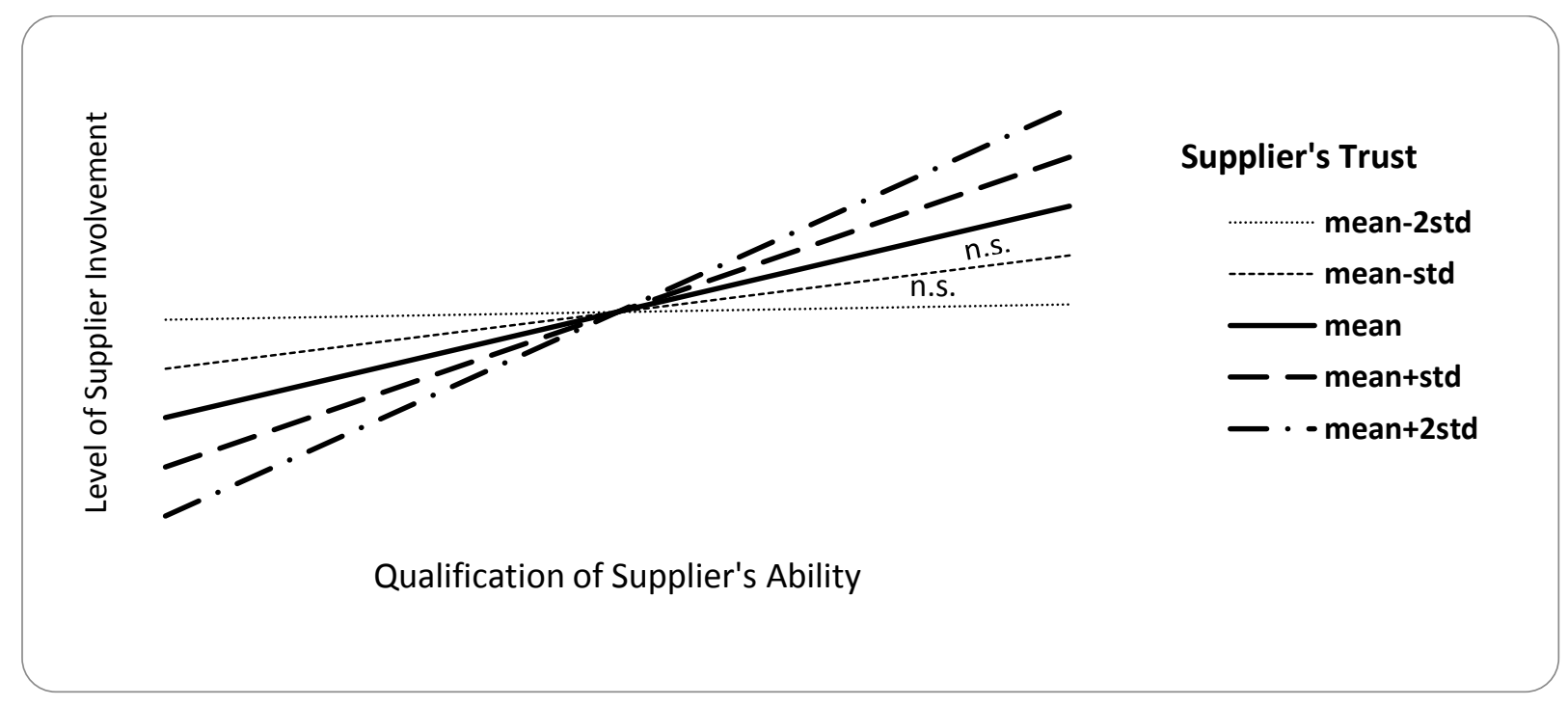


Reviewers' comments:

1-In the introduction section page 3, you have stated: "So far, the literature on this topic is scarce and inconclusive". For me as a reader still the gap is not demonstrated. You need to reformulate the discussion before this claim.

Done. This is an excellent suggestion and we hope we have significantly improved the positioning of this manuscript and its contribution. We have removed this sentence, and replaced it with a discussion of why the literature is inconclusive - since the extant studies have focused on short-term antecedents, while there has been a call to examine factors with a longterm impact on supplier involvement and may change through time. We note:

"...the literature on this topic has focused on antecedents to supplier involvement (such as supplier's specific investments and startup's qualification of supplier's capability (Song \& Di Benedetto 2008)), without regard for factors that may change through time and either maintain the supplier's desire to continue working with the startup, or cause an initially favorable supplier-startup relationship to erode, and diminish the supplier's intention to stay involved in the long term."

We further point out why we selected trust and equity share as antecedents in our study: these both have longer term effects that can offset and erosion in supplier involvement through time. To this end, near the end of the introduction section, the following brief statement is added

“...building trust and offering an equity share are actionable mechanisms that can be used by the startup to maintain, or even further grow, the supplier's initial levels of trust into the long term, and offset any possible decline in the effectiveness of the mechanisms that characterized the relationship in its initial stages (Le Breton-Miller \& Miller, 2006).

2-In the conceptual framework section, please discuss why you have choose only supplier equity share and trust as two contingency roles of supplier, why not others. For instance, instead of trust, why not commitment? Or beside trust, why not capability (technical). More clarification is needed in this matter.

Done. In our framework, we treat specific investment by the suppliers and qualification of supplier's ability by the startup as measures of commitment and capability. We examine how trust and equity moderate the impact commitment and capability. We have clarified this in this revision. For your convenience, we copy the revised text below:

“In our framework (see Figure 1), the startup's effort in qualifying suppliers (qualification of supplier's abilities) is a specific investment by the startup, while the supplier's specific investment is the investment by the supplier in the partnership, both of which are intentional mechanisms implemented by the relationship partners to reduce transaction risk and build initial trust. These represent the commitment and qualification of capabilities of the partners. The results from Song and Di Benedetto (2008) suggest that supplier's specific investment and qualification of supplier's abilities are positively related to the level of supplier's involvement in the startup's innovation. However, we argue that 
these initial commitment and qualification of capability may not be sufficient in an entrepreneurial setting, and their effects can be of short-term, while the evolving startup's innovation requires the supplier make a longer-term commitment and develop its capabilities over a longer period time to meet the startup's evolving needs. Startups can design and develop formal and informal governance to maintain and grow the initial commitment and qualification of the relationship partners. Equity share and trust have been identified as formal and informal governance mechanisms. We propose that the startup can motivate the supplier to increase its commitment to the startup's innovation by building trust through time (once the relationship is initiated as each party becomes more familiar with the other) and offering the supplier equity shares."

3-The Discussion is too brief. Please refer back to the discussion in the conceptual framework.

Thank you. We have made an attempt to extend and elaborate the discussion of results, and to tie back to the conceptual framework and emphasize the longer-term effects where possible. Among other changes, we did the following:

- At the end of the first paragraph of the discussion, we added this statement to emphasize our contribution regarding the process of supplier involvement: “...the findings of our study expand the extant supplier involvement literature by demonstrating that supplier involvement in startup settings is a distinctive process that is due to startup-specific contingencies."

- We re-emphasize the finding that equity share has a moderating effect on supplier's specific investment and qualification of supplier's abilities, leading to greater supplier involvement and better performance in the long term. In particular, we state: "...startups can choose effective means that suit their specific situation. (The results) reveal that these means (i.e., equity share) must not necessarily be of high present value to attract suppliers, but rather that it is more important that they reflect the potential for a long-term positive horizon."

- We note also the role of trust in the long term, as a moderator of the relationships between supplier's specific investments, qualification of supplier's abilities, and supplier involvement. We note that our findings are consistent with the literature that demonstrates that trust has a complementary effect: "once the supplier highly trusts the startup, it will be more willing to take risks and to develop stronger bonds with the startup."

4-You have discussed some implications which are interesting. But please don't mix the limitations with your theoretical contributions.

Done. Thank you for this excellent suggestion. We have reorganized the concluding section into: Discussion and Theoretical Implications; Implications for Management; and Limitations and Future Research Directions. We have carefully reorganized the content so it fits appropriately into these three subsections. Thanks to this point and the previous one raised by the reviewer, we believe the concluding section is now much stronger as a result.

I hope these comments will help you to improve the paper and good Luck. 
Thank you for the encouraging comments and excellent suggestions! We hope that our changes in this draft meet with your approval. 